\title{
White Cells and Bacteria in Voided Urine of Healthy Newborns
}

\author{
JAMES M. LITTLEWOOD \\ From Seacroft Hospital, Leeds
}

Littlewood, J. M. (1971). Archives of Disease in Childhood, 46, 167. White cells and bacteria in voided urine of healthy newborns. During a screening survey for urinary infection, 600 infants had one or more urines examined on the sixth or seventh day of life and 592 were subsequently shown to be uninfected. Bacterial and white cell counts on the first urine specimen to be examined from each infant are reported, comprising 363 specimens (188 from boys, 177 from girls) collected into plastic bags and 229 specimens (116 from boys, 113 from girls) collected by a clean catch technique.

Bag specimens contained 5 white cells per $\mathrm{mm}^{3}$ or less in $98 \%$ of boys but in only $56 \%$ of girls, in whom $11 \%$ contained more than 100 white cells per $\mathrm{mm}^{3}$. Clean catch specimens contained up to 5 white cells per $\mathrm{mm}^{3}$ in $97 \%$ of boys and $94 \%$ of girls, suggesting perineal contamination in girls to be the cause of the higher white cell counts in urine collected into plastic bags.

Total bacterial counts of 10,000 colonies per $\mathrm{ml}$ or less were obtained from bag urines in $41 \%$ of both boys and girls and from midstream urines of $73 \%$ of boys and $77 \%$ of girls. Midstream specimens were significantly better than bag specimens for purposes of culture.

Examination of voided urine specimens from newborns allows infection to be excluded in approximately $45 \%$ of infants if only one bag specimen is examined and in approximately $75 \%$ if a single midstream specimen is obtained. Even bag specimens are therefore not without value.

Suprapubic aspiration should be reserved for infants where difficulty arises due to repeated equivocal results from voided urines, when urgent confirmation is required, or when the presence of perineal lesions makes suitable voided urine collection impracticable.

During the course of a screening survey of newborn infants for the presence of urinary tract infection 600 infants had urine white cell counts and quantitative bacterial cultures performed on one or more specimens (Littlewood, 1969). The white cell counts and bacterial counts from the first urine specimens examined from 592 uninfected infants are reported in the present paper. They represent the findings to be expected from normal newborn infants when urine specimens are collected either into plastic bags or as clean catch specimens after cleansing the perineum by a standard procedure. Eight infants found to have urinary tract infection have been reported elsewhere (Littlewood, Kite, and Kite, 1969).

Received 15 August 1970.

\section{Material and Methods}

Every infant who was in the Leeds Maternity Hospital at the age of 6 days and who was not receiving antibiotic therapy was included. The survey lasted 125 days between April and August 1967. Urine specimens were collected by the midwives either in the lying-in wards or in the special care baby unit.

On the sixth day, after the morning bath, the external genitalia were cleansed with hexachlorophane (Phisohex) for one minute; this was then removed with a sterile swab. Benzalkonium chloride $(1: 1000)$ was then applied in single strokes six times, using a fresh swab impregnated with solution each time. The perineum was then thoroughly dried (Pryles, 1965).

Urines were collected either as 'clean catch' specimens or into sterile plastic bags` ('bag specimens'). A few

\footnotetext{
^Portex Paediatric Disposable Urine Collector.
} 
urine specimens were obtained by suprapubic aspiration to confirm the presence of bacteriuria in the infected infants: these are not included in the present series.

Urines collected into plastic bags were transferred to the laboratory in the bags, the time of application and removal of the container being noted. Clean catch specimens were transferred in the small sterile bowl into which they had been collected.

Urines were usually examined within three hours of collection and all specimens were stored at $4^{\circ} \mathrm{C}$, from the time of voiding until culture.

Collection of Clean Catch Urines. Different techniques were used to stimulate micturition. Though more time may be expended in obtaining a clean catch urine than in the collection of a bag specimen, the superiority over bag specimens for purposes of culture became obvious at an early stage of the study. Our experience with the Perez reflex was disappointing (Boehm and Haynes, 1966). Though any procedure tried was more effective when the infant had been fed and had not yet passed urine, or alternatively had been dry for 1 to $1 \frac{1}{2}$ hours, one method was found to be particularly effective-that described by Gallo and colleagues (1961). The infant lies supine and is cleansed as described above; the thighs are abducted by an assistant and sterile saline or water from a $20 \mathrm{ml}$ syringe is poured slowly over the external genitalia. The operator holds a small sterile dish in his free hand near the perineum ready to collect the midstream specimen.

White cell counts. These were performed on wellmixed uncentrifuged urine specimens using a FuchsRosenthal counting chamber. A variety of staining methods was employed, including the SternheimerMalbin (Sternheimer and Malbin, 1949), methylene blue, and the differential leucocyte stains (Prescott and Brodie, 1964). The differential leucocyte stain was particularly useful in differentiating non-squamous epithelial cells from white blood cells, though confusion could still arise if the peroxidase activity of the white cells was reduced for any reason. This stain is unreliable in the presence of heavy pyuria (W. Brumfitt, 1968, personal communication).

Quantitative bacterial counts. Surface viable counts were performed on every specimen. A known volume of well-mixed urine was pipetted onto the surface of a blood agar plate using a sterile disposable micropipette ('Microcap' pipettes; Shandon Laboratories Ltd.). The urine so delivered was evenly distributed over the surface of the medium with a sterile ' $L$ '-shaped glass rod. $10 \mu \mathrm{l}$ and $1 \mu \mathrm{l}$ quantities were used, two plates being used for each specimen. A loopful was also plated onto McConkey medium to aid identification of the organisms. The colonies growing from the $10 \mu \mathrm{l}$ and $1 \mu$ l quantities after overnight incubation were multiplied by either 100 or 1,000 respectively to give the total colony count per millilitre of the original specimen.

This method of quantitative culture compares very favourably with the classical pour plate method, and further details will be reported elsewhere (P. Kite, 1970, personal communication).

\section{Results}

Urines growing fewer than 10,000 colonies per $\mathrm{ml}$ were considered to be contaminated. During the course of the survey there were 65 infants (26 males, 39 females) who were discharged home before a colony count of less than 10,000 per ml could be achieved. However, only 30 of these infants were discharged with counts of more than 50,000 colonies per $\mathrm{ml}$; in the majority of these, failure to obtain counts below 10,000 per ml had been prevented only by the infants' discharge from hospital. In the majority there was no associated celluria, and in others, where more than one specimen had been obtained, different organisms had been isolated from successive specimens, suggesting contamination and making the possibility of either having originated from the bladder remote.

Of these 30 infants with counts of more than 50,000 colonies per $\mathrm{ml}, 9$ had further specimens examined after discharge: all were uninfected at the time of follow up. All the infants were reported to be thriving and there was no reason to suppose that any infant with urinary infection had been included in the present series.

Urine white cell count (Fig. 1-4). No attempt has been made to suggest an upper limit of 'normal' but absolute figures and percentages are given in detail to illustrate findings to be expected from uninfected newborn infants who have been cleaned

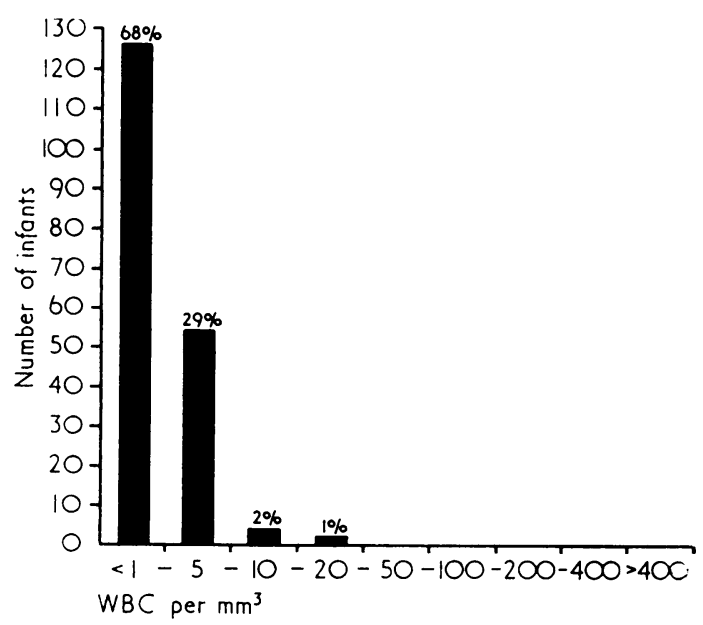

FIG. 1.-Urine white cells (boys): bag urines (186 infants). 


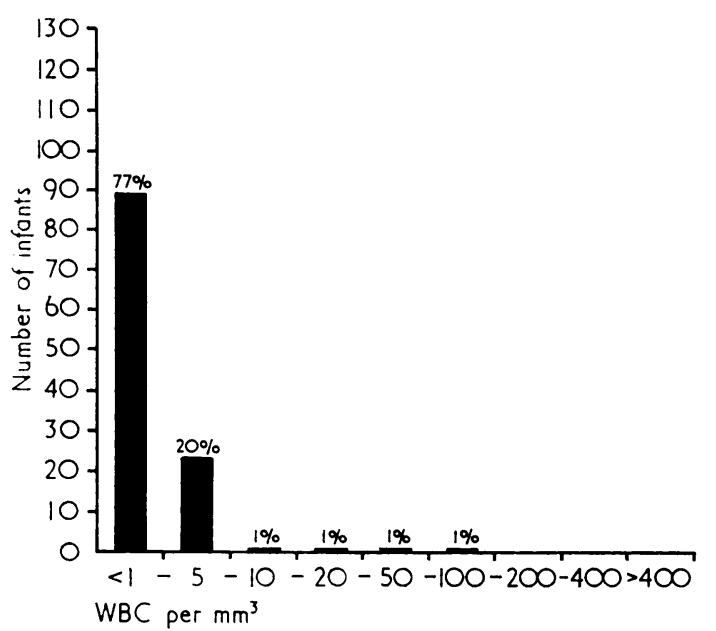

FIG. 2.-Urine white cells (boys): clean catch (116 infants).

as described and where specimens have been collected either into plastic bags or by the clean catch method.

Within the group of urines collected into plastic bags significantly higher white cell counts occurred in the females $\left(x^{2}=9.27 ; \mathrm{n}=5 ; \mathrm{P}<0.01\right)$.

If bag specimens and clean catch specimens from both sexes are compared, significantly lower white cell counts occurred from the clean catch specimens $\left(x^{2} 32 \cdot 6 ; \mathrm{n}=5 ; \mathrm{P}<0.01\right)$. However, this was due to the difference occurring in females $\left(x^{2} 35 \cdot 8 ; \mathrm{n}=5 ; \mathrm{P}<0 \cdot 01\right)$.

The clean catch method of urine collection is therefore associated with significantly lower white

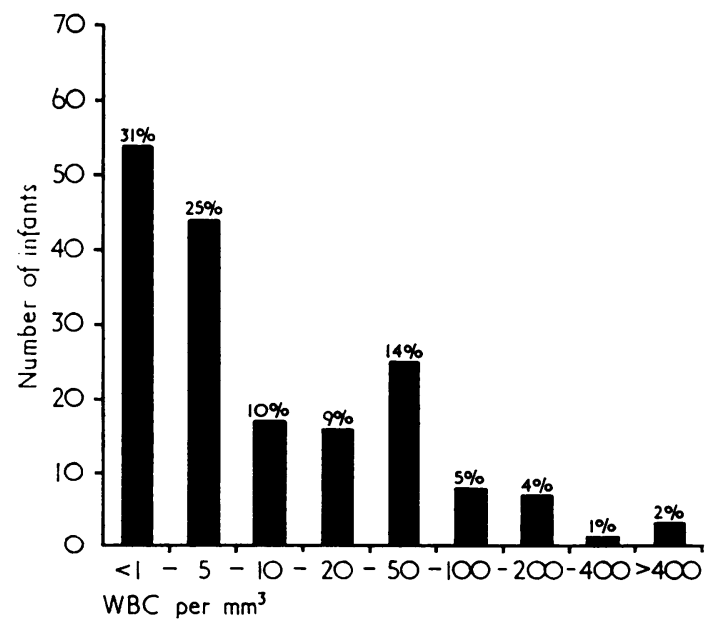

FIG. 3.-Urine white cells (girls): bag urines (175 infants). $\dagger$ tNo cell count from two infants.

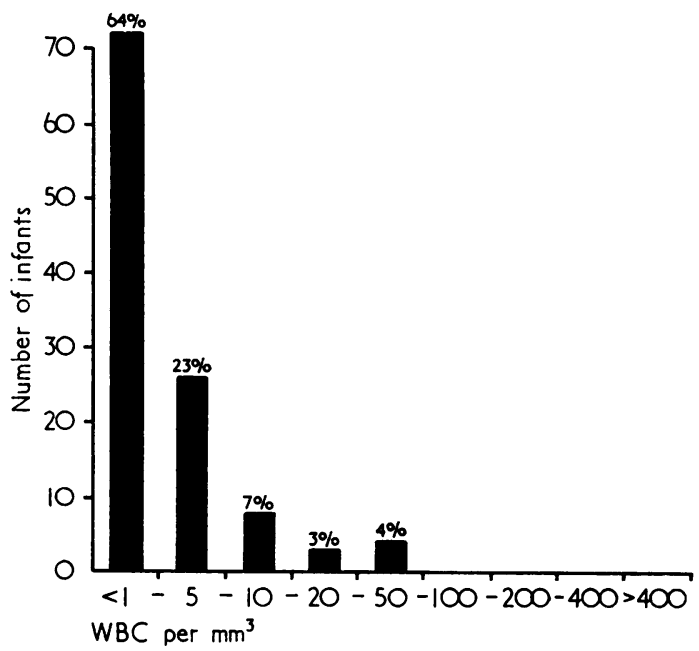

FIG. 4.-Urine white cells (girls): clean catch urines (113 infants).

cell counts in females, suggesting that the higher white cell counts in bag specimens are due to perineal contamination.

Bacterial counts (Fig. 5-8). The superiority of the clean catch method over bag collection is apparent from the lower bacterial counts obtained by the catch method in both sexes.

Bacterial counts from urines collected as clean catch specimens show no significant difference between the sexes $\left(\chi^{2} 1.909 ; \mathbf{n}=3 ; 0.7>P>0.5\right)$

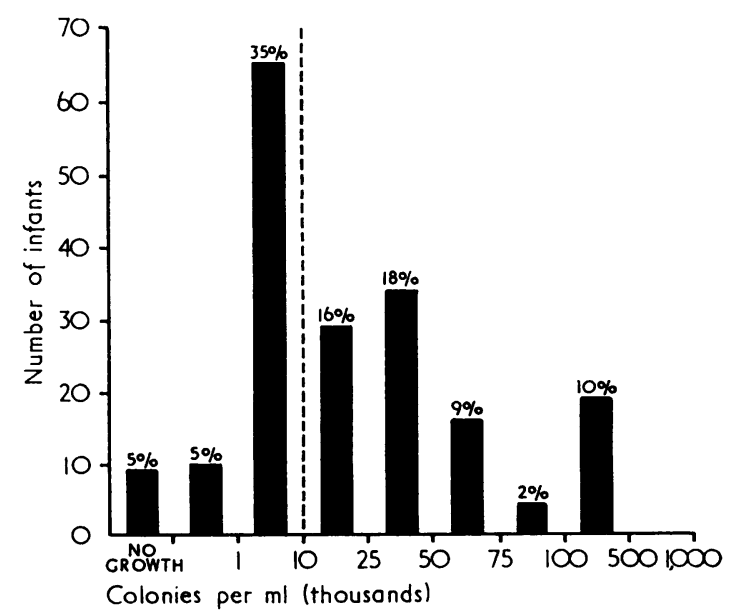

FIG. 5.-Urine bacterial counts (boys): bag urines (186 infants). 


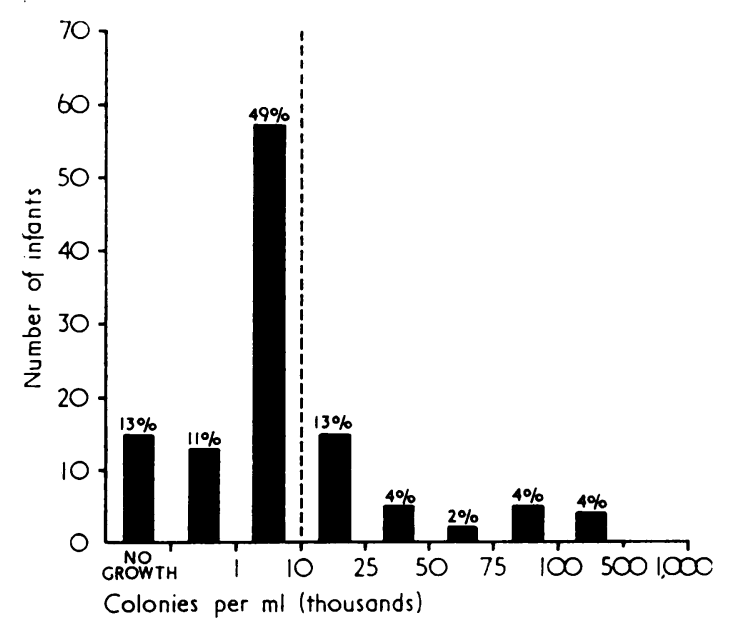

FIG. 6.-Urine bacterial counts (boys): clean catch urines (116 infants).

and those into plastic bags only a borderline difference-lower counts occurring in males $\left(x^{2} 6 \cdot 67 ; \mathrm{n}=3 ; 0 \cdot 1>\mathrm{P}>0.05\right)$.

When bag and clean catch urines are compared there are significantly lower counts obtained by the catch method ( $\left.\chi^{2} 58 \cdot 7 ; \mathrm{n}=3 ; \mathrm{P}<0 \cdot 01\right)$.

Approach to diagnosis. It has been suggested that information obtained from examination of voided urine is of little value when specimens are collected into plastic bags, and that the collection of suitable midstream specimens for quantitative bacterial culture is impracticable in the newborn

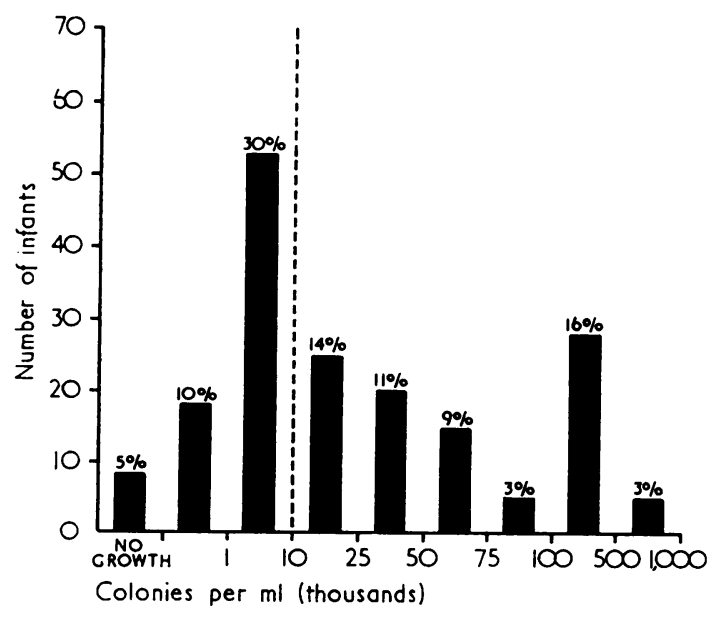

Fig. 7.-Urine bacterial counts (girls): bag urines (177 infants).

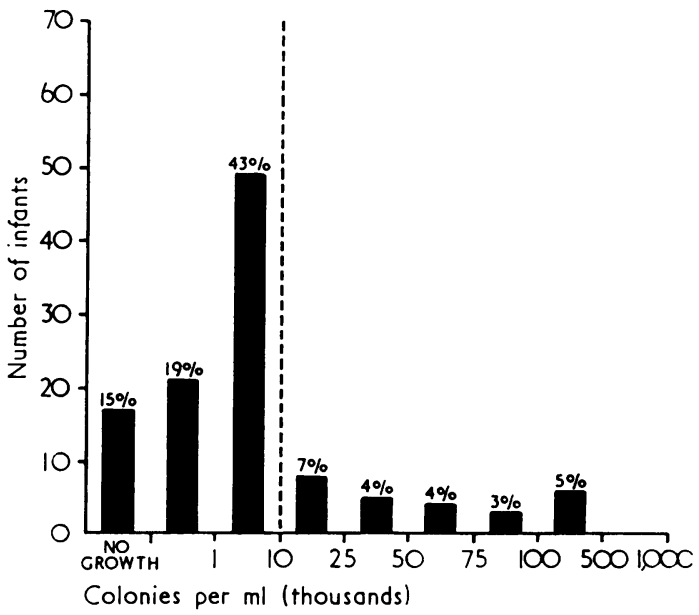

FIG. 8.-Urine bacterial counts (girls): clean catch urines (113 infants).

(Newman, O'Neill, and Parker, 1967). The present study indicates that this is not entirely true. The eight infants found to have urinary tract infection during the course of the survey were separated from the uninfected population before the presence of infected bladder urine was confirmed by suprapubic aspiration (Littlewood et al., 1969).

The writer does not believe that 'diagnostic levels' of either pyuria or bacteriuria applied to one voided urine specimen are entirely satisfactory and it should be noted that Kass's classical dividing line of 100,000 colonies per $\mathrm{ml}$ between 'contaminated' and 'infected' specimens has only an $85 \%$ accuracy when applied to a single midstream specimen in adults (Kass, 1957). It is true that in many newborns with urinary tract infection, the numbers of white cells and bacteria visualized on direct microscopy leave little doubt that the urine is heavily infected. Nevertheless acceptance of diagnostic levels of bacteriuria and certainly of pyuria on one specimen will lead to frequent false positives, with consequent unnecessary treatment and investigation. The author believes that particularly in female infants, but also in males, there is no level of pyuria which is diagnostic of urinary tract infection at this or any other age, and that the presence of infection can only be confirmed by the demonstration of significant bacteriusia. Allowing this to be true, it is common experience that in the male newborn pyuria is frequently helpful in confirming the significance of a high bacterial count (in contrast to female newborns) and it is unusual to find more than 10 white cells per $\mathrm{mm}^{3}$ in the absence of infection. 
The diagnosis of neonatal urinary tract infection has been approached in a variety of ways. The first has been to raise the level of significance from 100,000 to 500,000 colonies per $\mathrm{ml}$ (Masters and Lewis, 1965) or even millions per $\mathrm{ml}$ (Braude et al., 1967), i.e. to accept and make allowance for the greater bacterial contamination which accompanies voiding and collection of urine when containers are attached to the perineum. This has the disadvantage that a small number of infected infants, who nevertheless do not have very high bacterial counts, will be incorrectly considered to be uninfected; the higher the level of 'significance' is placed, the more frequently will this error occur.

The second approach has employed more direct methods of collection in doubtful cases, e.g. catheterization (McCarthy and Pryles, 1963) or suprapubic aspiration of the bladder (Nelson and Peters, 1965; Newman et al., 1967).

A third approach involves reduction of the external contamination by meticulous and prolonged cleansing to lengths which are alleged to make its application unacceptable for routine use (Lincoln and Winberg, 1964). An alternative is to use a routine cleansing procedure (Pryles, 1965) and to collect the urine into a sterile container not attached to the perineum, i.e. a midstream or clean catch specimen is obtained (Boehm and Haynes, 1966; Braude et al., 1967; Cruickshank and Edmond, 1967).

Braude and his colleagues (1967) showed that containers applied to the perineum may be heavily contaminated even before voiding occurs. Using a clean catch technique, urine specimens growing fewer than 10,000 colonies per $\mathrm{ml}$ can be obtained from $75-85 \%$ of both uninfected boys and girls compared with less than $50 \%$ of specimens (from both sexes) when plastic bags or other containers are attached to the perineum. However, before discounting the results of culture of bag urines as of no value, it should be noted that some $50 \%$ of infants of both sexes can be shown to be definitely uninfected after examination of only one such specimen.

The author does not accept the first method as desirable for reasons given above; he has adopted the approach combining the second and third alternatives; in particular, reliance has been placed on repeated voided urines, great efforts being made to obtain clean catch specimens whenever possible. Only when all else fails has resort been made to suprapubic aspiration (as a preferable method to catheterization) for absolute confirmation of infection in equivocal cases.

It has been found helpful to classify newborn infants into the following categories when interpreting the results of voided urine examination.

(a) Those where the urinary findings on at least two voided specimens are so far removed from the normal with regard to both bacteria and white cells that further examination is unnecessary, e.g. the infant with many thousands of white cells per $\mathrm{mm}^{3}$ and many millions of bacteria per $\mathrm{ml}$ uncentrifuged urine: they are considered to be infected. Though it may be argued that these are 'diagnostic levels' the finding of thousands of white cells per $\mathrm{mm}^{3}$ and many millions of bacteria per $\mathrm{ml}$ far exceed previously suggested criteria for these age groups (Braude et al., 1967).

(b) The infant from whom a voided urine (whether 'bag' or 'clean catch') grows fewer than 10,000 colonies per ml uncentrifuged urine; frequently there is also a low white cell count (10 $\mathrm{mm}^{3}$ ). Evidence suggests that the chances of these infants having true bacteriuria are remote (McCarthy and Pryles, 1963). These infants are considered to be uninfected. Provided the infant is not receiving chemotherapy, bacterial counts of fewer than 10,000 per ml even when accompanied by a white cell count in excess of 10 per $\mathrm{mm}^{3}$ are considered to be due to contamination.

(c) Infants from whom repeated voided specimens (if possible collected by the clean catch technique) show bacterial counts of more than 10,000 per ml (irrespective of the white cell count) yet who fail to produce specimens which are obviously infected (as in group (a)) or obviously uninfected (as in (b)).

Evaluation of group (c) requires particular consideration. The opportunity is taken to examine as many specimens as possible from these infants. After the first 'bag urine' has shown a high bacterial count particular care is taken with the cleansing procedure for the second specimen. If the second specimen has a high bacterial count an attempt is made to obtain a clean catch specimen. If a clean catch specimen is not obtained, or if a result from such a specimen is equivocal, or if the condition of the perineum is such that there is a probability that contamination is occurring, a specimen is obtained by suprapubic aspiration of the bladder.

Though this approach to diagnosis is somewhat time consuming, it has the advantage that only a few infants are subjected to methods of urine collection other than by plastic bags or as clean catch specimens. Furthermore, doubtful cases are categorized as either uninfected or infected.

It is considered that the accurate diagnosis to this condition is important and the time expended is fully justified. It is unreasonable to expect a firm diagnosis to be made in every case on the result of 
only one voided urine. If the diagnosis must be made on one specimen then the criteria of Braude et al. (1967) are as good as any, with the reservations mentioned above. However, if such urgency exists and the clinical condition requires an immediate decision a suprapubic aspiration is both justifiable and desirable.

I thank Professor W. S. Craig, Dr. William Brumfitt, and Professor R. W. Smithells for advice and help, the sisters and midwives of the Leeds Maternity Hospital; and Mr. Peter Kite, F.I.M.L.T., and Mrs. Beverley Kite for the contribution to the bacteriological work.

\section{REFERENCES}

Boehm, J. J., and Haynes, J. L. (1966). Bacteriology of 'midstream catch' urines. American fournal of Diseases in Children, 111, 366.

Braude, H., Forfar, J. O., Gould, J. C., and McLeod, J. M. (1967). Cell and bacterial counts in the urine of normal infants and children. British Medical fournal, 4, 697.

Cruickshank, G., and Edmond, E. (1967). 'Clean catch' urines in the newborn: bacteriology and cell excretion patterns in first week of life. British Medical fournal, 4, 705.

Gallo, A., Zamorano, M., Cabrea, F., Alvo, M., Vivanco, A., Tobar, J., and Carmona, E. (1961). Evaluation de examen de orina elemento de diagnostico en las infecciones urinarieas agudsa del lactante. Revista Chilena de Pediatria, 32, 621.

Kass, E. H. (1957). Bacteriuria and the diagnosis of infections of the urinary tract, with observations on the use of methionine as a urinary antiseptic. Archives of Internal Medicine, 100, 709.
Lincoln, K., and Winberg, J. (1964). Studies of urinary tract infection in infancy and childhood. III. Quantitative estimation of cellular excretion in unselected neonates. Acta Paediatrica, 53, 447.

Littlewood, J. M. (1969). 'Urinary tract infection in the newborn with special reference to variations on symptomatology and ultimate prognosis. M.D. Thesis, University of Leeds.

Littlewood, J. M., Kite, P., and Kite, B. A. (1969). Incidence of neonatal urinary tract infection. Archives of Disease in Childhood, 44, 617.

McCarthy, J. M., and Pryles, C. V. (1963). Clean voided and catheter neonatal urine specimens. American fournal of Diseases in Children, 106, 473.

Masters, P. L., and Lewis, I. G. (1965). Urinary infection in childhood. British Medical fournal, 1, 856.

Nelson, J. D., and Peters, P. C. (1965). Suprapubic aspiration of urine in premature and term infants. Pediatrics, 36, 132.

Newman, C. G. H., O'Neill, P., and Parker, A. (1967). Pyuria in infancy, and the role of suprapubic aspiration of urine in diagnosis of infection of urinary tract. British Medical fournal, 1, 277.

Prescott, L. F., and Brodie, D. E. (1964). A simple differential stain for urinary sediment. Lancet, 2, 940.

Pryles, C. V. (1965). Percutaneous bladder aspiration and other methods of urine collection for bacteriologic study. Pediatrics, 36, 128.

Sternheimer, R., and Malbin, B. I. (1949). A new stain for urinary sediments: its value in the differential diagnosis of hypertension. (abstr.). American Heart fournal, 37, 678.

Correspondence to Dr. J. M. Littlewood, Seacroft Hospital, York Road, Leeds LS14 6UH. 